\title{
Large atrial mass in a patient with Crohn's disease: organised thrombus mimicking a myxoma
}

\author{
Erik Lerkevang Grove
}

- Additional material is published online only. To view please visit the journal online (http://dx.doi.org/10.1136/ bcr-2017-222044).

Department of Cardiology, Aarhus University Hospital, Aarhus, Denmark

Correspondence to Dr Erik Lerkevang Grove, erikgrove@dadlnet.dk

Accepted 18 August 2017

\section{CrossMark}

To cite: Grove EL. BMJ Case Rep Published Online First: [please include Day Month Year]. doi:10.1136/bcr-2017222044

\section{DESCRIPTION}

A right atrial mass was incidentally discovered on a CT in a 30-year-old female patient with an 11-year history of Crohn's disease. Medical treatment included infliximab and azathioprine. She denied chest pain, palpitations, orthopnoea or dyspnoea. Transoesophageal echocardiography showed a large, $2.9 \times 2.2 \mathrm{~cm}$, non-obstructive, mobile mass attached by a broad stalk to the lateral wall of the right atrium (online supplementary video 1 and figure 1). An atrial myxoma was suspected, and the tumour was completely extirpated. No other mass was found inside the atrium, and the cava veins were patent and free. Surprisingly, histological examination revealed an organised thrombus with no evidence of myxoma. The patient was discharged with long-term warfarin and had an uneventful recovery and no further episodes of thrombosis (2-year follow-up).

The most frequent causes of thrombus formation in the right atrium are transvenous pacing leads and prolonged central venous cathethers; however, there are a few reports of right atrial thrombi in patients with systemic inflammatory conditions, such as systemic lupus erythematosus and Behçet's disease. Patients with Crohn's disease are known to have a higher risk of thromboembolic events than

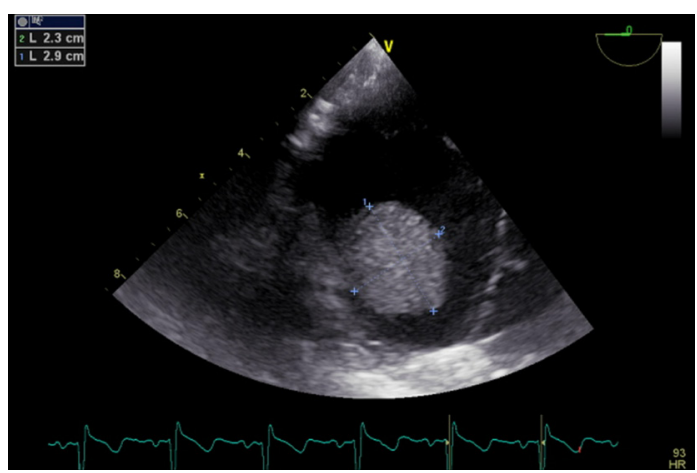

Figure 1 Transoesophageal echocardiogram showing a $2.2 \times 2.9 \mathrm{~cm}$ mass in the right atrium. the normal population, ${ }^{1}$ partly explained by inflammatory activity and prothrombotic abnormalities, including downregulation of natural anticoagulant mechanisms, increased platelet count, dysfunctional endothelium and impaired fibrinolysis.

An intracardiac mass poses a difficult diagnostic challenge because of similar echo densities of myxoma and thrombi. Contrast echocardiography helps distinguish thrombi without perfusion from tumours with varying degrees of perfusion. ${ }^{2}$

\section{Learning points}

- The type of cardiac tumours is indicated by the appearance and location of the tumour on echocardiography, but definitive classification is given by histopathological examination.

- For differential diagnostic purposes, MRI, contrast echocardiography or anticoagulant treatment will often be appropriate in patients with an intracardiac mass prior to cardiac surgery.

- Thrombus formation should be considered as a rare differential diagnosis of intracardiac masses in patients with systemic inflammatory conditions such as Crohn's disease.

Contributors ELG was responsible for all steps in the preparation of this manuscript.

Competing interests None declared.

Patient consent Obtained.

Provenance and peer review Not commissioned; externally peer reviewed.

(c) BMJ Publishing Group Ltd (unless otherwise stated in the text of the article) 2017. All rights reserved. No commercial use is permitted unless otherwise expressly granted.

\section{REFERENCES}

1 Magro F, Soares JB, Fernandes D. Venous thrombosis and prothrombotic factors in inflammatory bowel disease. World J Gastroenterol 2014;20:4857-72.

2 Kirkpatrick JN, Wong T, Bednarz JE, et al. Differential diagnosis of cardiac masses using contrast echocardiographic perfusion imaging. J Am Coll Cardiol 2004;43:1412-9. 
Copyright 2017 BMJ Publishing Group. All rights reserved. For permission to reuse any of this content visit http://group.bmj.com/group/rights-licensing/permissions.

BMJ Case Report Fellows may re-use this article for personal use and teaching without any further permission.

Become a Fellow of BMJ Case Reports today and you can:

- Submit as many cases as you like

- Enjoy fast sympathetic peer review and rapid publication of accepted articles

Access all the published articles

- Re-use any of the published material for personal use and teaching without further permission

For information on Institutional Fellowships contact consortiasales@bmjgroup.com

Visit casereports.bmj.com for more articles like this and to become a Fellow 